\title{
Effects of Design and Construction on the Carbon Footprint of Reinforced Concrete Columns in Residential Buildings
}

\author{
E. Fraile-Garcia $₫$, J. Ferreiro-Cabello ${ }^{\mathrm{a}}$, F.J. Martínez de Pison ${ }^{\mathrm{b}}$, A.V. Pernia-Espinoza ${ }^{\mathrm{b}}$ \\ a. Department of Mechanical Engineering, Structures Construction and Development of \\ Industrial Processes.SCoDIP Group, University of La Rioja (Spain) \\ b. Department of Mechanical Engineering, Engineering Data Mining And Numerical Simulation. \\ EDMANS Group, University of La Rioja (Spain) \\ \esteban.fraile@unirioja.es
}

Received 25 September 2018

Accepted 31 January 2019

Available on line 10 June 2019

\begin{abstract}
Constructing structural elements requires high performance materials. Important decisions about geometry and materials are made during the design and execution phases. This study analyzes and evaluates the relevant factors for reinforced concrete columns made in situ for residential buildings. This article identifies and highlights the most sensitive aspects in column design: geometry, type of cement, and concrete strength performance. Using C-40 concrete mixed with CEM-II proved to cut costs (up to $17.83 \%$ ) and emissions (up to $13.59 \%$ ). The ideal combination of rebar and concrete is between 1.47 and 1.73: this is the percentage of the ratio between the area of rebar and the area of the concrete section. The means used during the execution phase affect resource optimization. The location of a building has only a minor impact, wherein the wind zone exercises more influence than topographic altitude.
\end{abstract}

KEYWORDS: Portland cement; Concrete; Metal reinforcement; Mechanical properties; Modelization

Citation/Citar como: Fraile-Gracía, E.; Ferreiro-Cabello, J.; Martínez de Pisón, F.J.; Pernia-Espinoza, A.V. (2019) Effects of Design and Construction on the Carbon Footprint of Reinforced Concrete Columns in Residential Buildings. Mater. Construcc. 69 [335], e193 https://doi.org/10.3989/mc.2019.09918

RESUMEN: Efectos del diseño y la construcción sobre la huella de carbono en columnas de hormigón armado para edificios residenciales. La construcción de elementos estructurales requiere materiales de alto rendimiento. Las decisiones sobre la geometría y materiales se toman durante las fases de diseño y ejecución. Este estudio analiza y evalúa factores relevantes para columnas de hormigón armado en edificios residenciales. El trabajo identifica y resalta los aspectos más sensibles en el diseño de columnas: geometría, tipo de cemento y rendimiento de resistencia del concreto. El uso de hormigón C-40 mezclado con CEM-II demostró reducir costes (hasta 17.83\%) y emisiones (hasta $13.59 \%$ ). La combinación ideal de barras de refuerzo y concreto está entre 1.47 y 1.73: este es el porcentaje de la relación entre área de barras de refuerzo y área de la sección de hormigón. Los medios utilizados durante la fase de ejecución afectan la viabilidad de optimizar los recursos. La ubicación del edificio tiene un impacto menor, la zona eólica ejerce más influencia que la altitud topográfica.

PALABRAS CLAVE: Cemento Portland; Hormigón; Refuerzo metálico; Propiedades mecánicas; Modelización

ORCID ID: E. Fraile-Garcia (https://orcid.org/0000-0001-9408-5575); J. Ferreiro-Cabello (https://orcid.org/00000001-6489-0418); F.J. Martínez de Pison (https://orcid.org/0000-0002-3063-7374); A.V. Pernia-Espinoza (https://orcid. org/0000-0001-6227-075X)

Copyright: (C) 2019 CSIC. This is an open-access article distributed under the terms of the Creative Commons Attribution 4.0 International (CC BY 4.0) License. 


\section{INTRODUCTION}

The construction sector plays an important role in bolstering a country's economy. All economic activities have environmental and social impacts. The manufacture and construction of structural elements requires high performance materials and represents a significant percentage of the embodied impact (1). The production of reinforced concrete utilizes: structural steel, aggregates, water and Portland cement. Significant amounts of energy and resources are necessary to procure steel and cement (2).

The reinforced concrete sector is rising to the challenge of decreasing its carbon footprint $(3,4)$. And in order to reduce $\mathrm{CO}_{2}$ emissions, planners and builders rely on the tools currently available. Life cycle analysis tools, in their diverse formats, have been utilized to examine different structural materials. This is done by, for example, comparing two different construction materials (wood vs. concrete) (5) or comparing recycled aggregates to natural ones (6). The most significant indicators are: carbon footprint, which must be considered when selecting a structural system for a building (7) and the embodied energy parameter employed to compare structural systems $(8,9)$ and to evaluate new materials in the construction of load-bearing structural walls. Combining various indicators into Ecoindicators also facilitates the evaluation of structural options, such as in the case of one-way slabs (10).

The geometrical definition, loads and materials used in the configuration of structural elements made of reinforced concrete dictate the amount of rebar necessary. This relationship is much more pronounced in the case of columns as compared to beams (11). These two components constitute the primary structure of residential buildings.

Columns can be prefabricated or made in situ. In the case of precast columns, the $\mathrm{CO}_{2}$ emissions generated during their production have been examined and are estimated at $609.59 \mathrm{~kg}$ of $\mathrm{CO}_{2}$ for a single specific column (12). Other studies have investigated how to cut down on the resources and materials consumed on site and propose efficient designs for precast composite columns (13). By applying the lean production philosophy promoted by the automobile industry to precast reinforced concrete, a $5.8 \%$ reduction in $\mathrm{CO}_{2}$ emissions was obtained for a specific type of column (14). It was also found that the installation phase of a specific type of column generated $20.9 \mathrm{~kg}$ of $\mathrm{CO}_{2}$ emissions. Thus, it was concluded that by applying the lean philosophy to this process, emissions generated during the installation phase would decrease (15).It should be noted that the greatest environmental impact is generated during the production phase.

Different strategies have been tested on columns made in situ. On the one hand, combining large portions of concrete and high-strength materials has proven effective for high-rise buildings (35 floors) from an economic and environmental standpoint (2). In a similar building, the possibility of making composite steel-reinforced concrete columns was evaluated. Satisfactory results were obtained using circular sections and the space occupied by the columns was also reduced $(16,17)$. The optimal design for columns depends on whether the objective is to minimize costs or $\mathrm{CO}_{2}$ emissions (18).

For both types of columns, prefabricated or made in situ, most emissions are produced during the steel and cement procurement phase. One possible way to reduce $\mathrm{CO}_{2}$ emissions is to replace traditional binder (Clinker) with industrial by-products. Incorporating fly ash and blast furnace slag negatively impacts the service life of structural elements. However, this adverse effect is compensated by a reduction in emissions during the production phase $(19,20)$. The substitution rate of Clinker for fly ash must be below $20 \%$ in order to be advantageous in environmental terms (21). Assessing performance according to the substitution rates indicates that the maximum limit for silica fume is $10 \%$ and $15 \%$ for fly ash (22). The resulting structural behavior is similar to that of Portland cement (23). Following this line of research, tests have been conducted using cement with a high slag content for columns subjected to seismic actions. The results indicate the viability of this alternative (24). In the manufacture of composite columns, the structural response of cement with a high slag content has also proven to be satisfactory $(25,16)$. Meanwhile, structural steel manufacturers have successfully incorporated significant amounts of recycled steel scrap to minimize $\mathrm{CO}_{2}$ emissions (26).

In response to our global society's increasing awareness of environmental problems, the cement and steel sectors have designed environmental product declarations specifically for their sectors (26-31). These documents provide up-to-date environmental information on a representative sample of the companies involved in the development of a given product. Decisions regarding structural options should ideally be made based on environmental product declarations (32). It should also be noted that incorporating aggregates into cement reduces $\mathrm{CO}_{2}$ emissions (33).

By accurately sizing and predicting the amounts of materials used in column design (steel and concrete), the environmental impact can be significantly reduced (4). It is essential to determine the factors that can determine optimal column design (34). Resorting to precast columns is a logical choice in projects where timing and costs are of utmost importance. In terms of environmental impact, however, this option leads to greater $\mathrm{CO}_{2}$ emissions (35).

To quantify the life cycle emissions of reinforced concrete structures, a variety of real engineering 
data and an empirical study of many cases must be employed to establish their standard value (36). This study evaluates and quantifies the parameters that affect the design of reinforced concrete columns made in situ for residential building structures. From a societal perspective, the use of local raw materials is strongly favored. Therefore, the data incorporated in this study includes environmental declarations for steel and the concrete used to build the same structure in different locations. Important decisions about geometry and materials are made during the design and execution phases. These decisions have environmental and economic costs that must be quantified. This article identifies and highlights the most sensitive aspects in column design: geometry, type of cement and concrete strength performance.

\section{METHODOLOGY}

In order to evaluate and quantify the different parameters of column design in residential buildings, we must first determine which parameters are relevant. Two types of parameters that affect the production of reinforced concrete columns can be identified. On the one hand are those determined during the project phase: location parameters, characteristics of the materials, and geometry of the sections. On the other hand, the execution phase is affected by the formwork methods and the type of cement used in concrete production.

A model was created of a $25 \times 25 \mathrm{~m}$ square residential building, with 36 columns arranged in a $5 \times 5$ meter grid to support eight floors. The vertical loads consist of the weight of the slabs $\left(4.1 \mathrm{kN} / \mathrm{m}^{2}\right)$, pavement $\left(1 \mathrm{kN} / \mathrm{m}^{2}\right)$, partitioning $\left(1 \mathrm{kN} / \mathrm{m}^{2}\right)$ and the service overload $\left(2 \mathrm{kN} / \mathrm{m}^{2}\right)$. Figure 1 displays the simulated model.
The effects of the different parameters were evaluated simultaneously for all the columns in the building. This evaluation was performed considering the $\mathrm{CO}_{2}$ emissions incurred by making the columns in situ and the economic cost of each proposal. The variable parameters considered are described below.

\subsection{Location}

This parameter primarily affects two values: wind loads and snow loads. Regulations establish typical wind loads, which were factored in as a horizontal action on the building. Spanish regulations were applied to this case study, and three areas - A, B, and $\mathrm{C}$ - were identified. The magnitude of the vertical snow load is largely determined by the topographic altitude of the building's location $(0,400$, or $800 \mathrm{~m})$. These two loads were combined with the vertical loads corresponding to the weight of the building and its intended use. These vertical and horizontal actions create structural tension on each section of the columns.

\subsection{Materials and Geometry}

In order to evaluate the materials comprising the columns, concrete and rebar, the concrete strength performance was varied, whereas that of the rebar remained consistent. During the concrete configuration process, the possibility of incorporating additional materials was examined. Thus, using different types of Portland cement (CEM-I, CEM-II) in the execution phase was considered.

The environmental product declarations issued by the cement sector provide information on the environmental impact incurred by the production of a given product (27-31). The various concrete mixes used at a concrete plant to obtain concrete
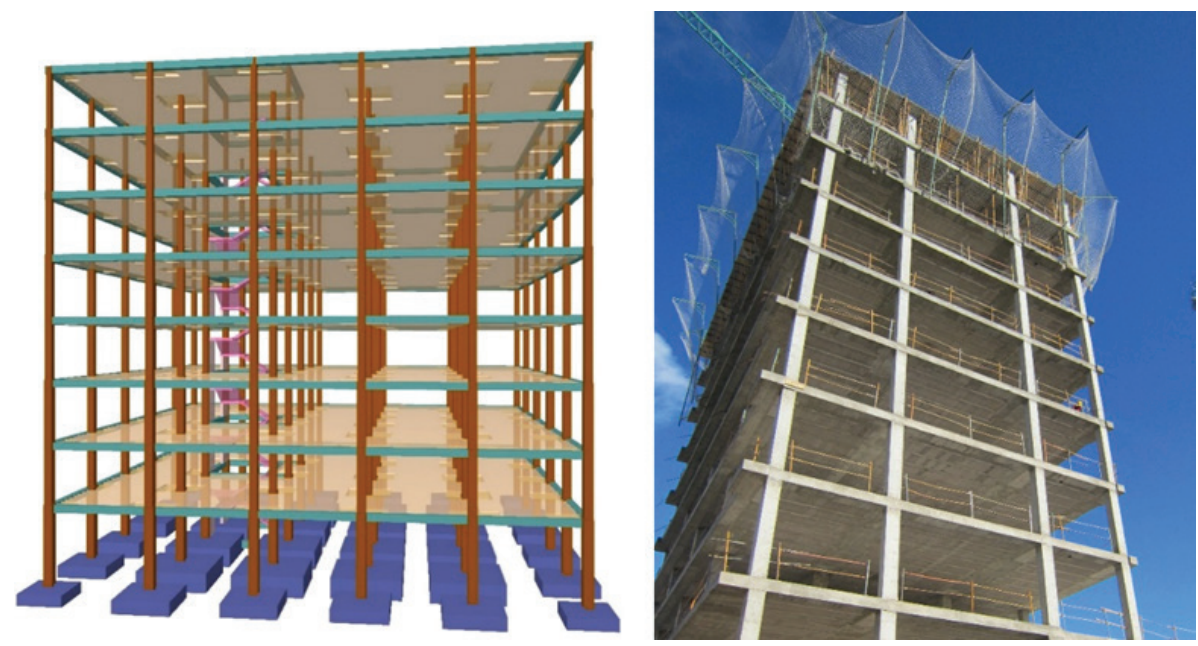

FIGURE 1. Modeled residential building. Actual building. 
of different strength performances were recorded. Therefore, the quantities of cement necessary to obtain concrete of different strengths, between 25 and $50 \mathrm{~N} / \mathrm{mm}^{2}$, were identified. Strength was varied in increments of $5 \mathrm{~N} / \mathrm{mm}^{2}$. Once the mixes of both cements were analyzed, the impact incurred during cement procurement was considered in order to assess the impact generated during concrete production. It is worth highlighting the following data from a past study of the ready-mix concrete industry (37): the impact of aggregate production and its incorporation into the concrete mix does not surpass $2 \%$, and the impact of transporting components and ready-mix concrete varies between $5 \%$ and $7 \%$. Table 1 lists the quantities of cement incorporated into each cubic meter of the different concrete mixes. Using different types of cement led to variations in the environmental and economic impacts. Table 1 shows the different values obtained for the manufacture and installation of 1 cubic meter of concrete. The economic costs were calculated based on a database from the construction sector (38). The environmental impact declared by the Spanish rebar sector was obtained following a similar procedure (26). Table 2 lists the cost and environmental impact generated by the manufacture and installation of $1 \mathrm{~kg}$ of rebar.
The different buildings were classified according to their location (A, B and C) and topographic altitude $(0,400$, or $800 \mathrm{~m})$. There are nine buildings with the same dimensions and variable loads. The columns of these buildings were sized using different concrete strengths $(25,30,35,40,45$ and $50 \mathrm{~N} / \mathrm{mm}^{2}$ ). Given the possibility of using different types of cement in the execution phrase, a solution map with 108 alternatives was created. The coding system consists of letters and numbers as indicated below (Table 3).

After determining the loads and the corresponding stresses to which the columns are subjected, the amount of rebar necessary was calculated.

TABLE 3. The coding system

\begin{tabular}{lccc}
\hline $\begin{array}{l}\text { Wind } \\
\text { zone }\end{array}$ & $\begin{array}{c}\text { Topographic } \\
\text { altitude in meters }\end{array}$ & $\begin{array}{c}\text { Design Strengths (fck) } \\
\text { Concrete N/mm }\end{array}$ & $\begin{array}{c}\text { Type of } \\
\text { cement }\end{array}$ \\
\hline & & 25 & \\
& & 30 & \\
A & 0 & 35 & I \\
B & 400 & 40 & II \\
C & 800 & 45 & \\
& & 50 & \\
\hline
\end{tabular}

TABLE 1. Economic and environmental costs of $1 \mathrm{~m}^{3}$ of concrete in columns, including labor

\begin{tabular}{|c|c|c|c|c|c|}
\hline & Materials & TypeCement & kg CEM & Cost $€$ & $\mathrm{~kg} \mathrm{CO}_{2} \mathrm{Eq}^{|27| \mid 28]}$ \\
\hline \multirow{12}{*}{$\mathbf{m}^{3}$} & Ready-mix concrete C-25 & \multirow{6}{*}{ CEM-I } & 275 & 103.24 & 243.045 \\
\hline & Ready-mix concrete C-30 & & 300 & 108.44 & 265.140 \\
\hline & Ready-mix concrete C-35 & & 325 & 114.98 & 287.235 \\
\hline & Ready-mix concrete C-40 & & 350 & 124.19 & 309.330 \\
\hline & Ready-mix concrete C-45 & & 375 & 133.18 & 331.425 \\
\hline & Ready-mix concrete C-50 & & 400 & 143.59 & 353.520 \\
\hline & Ready-mix concrete C-25 & \multirow{6}{*}{ CEM-II } & 300 & 103.84 & 225.690 \\
\hline & Ready-mix concrete C-30 & & 325 & 108.87 & 244.497 \\
\hline & Ready-mix concrete C-35 & & 350 & 115.24 & 263.305 \\
\hline & Ready-mix concrete C-40 & & 375 & 124.28 & 282.112 \\
\hline & Ready-mix concrete C-45 & & 400 & 133.11 & 300.920 \\
\hline & Ready-mix concrete C-50 & & 425 & 143.35 & 319.727 \\
\hline
\end{tabular}

TABLE 2. Economic and environmental costs of manufacturing and installing $1 \mathrm{~kg}$ of rebar in columns, including labor

\begin{tabular}{|c|c|c|c|}
\hline & Materials & Cost $€$ & $\mathrm{~kg} \mathrm{CO}_{2} \mathrm{Eq}^{[26]}$ \\
\hline \multirow[t]{3}{*}{ kg } & $\begin{array}{l}\text { Rebar B 500-S manufactured in industrial workshop. } \\
\text { UNE-EN } 10080 .\end{array}$ & 1.034 & 0.54567 \\
\hline & Binding wire $1.20 \mathrm{~mm}$ diameter. & 0.005 & 0.00273 \\
\hline & Direct cost of installing $1 \mathrm{~kg}$ rebar & $1.039 € / \mathrm{kg}$ & $0.5484 \mathrm{~kg}$ \\
\hline
\end{tabular}


An iterative calculation process was established in which the ratio $A_{s} / A_{c}$ was modified, where $A_{s}$ represents the steel section and $A_{c}$ the concrete section. This value is given as a percentage. The modification of this ratio $\left(\mathrm{A}_{\mathrm{s}} / \mathrm{A}_{\mathrm{c}}\right)$ incorporates the geometric variability of the project phase. The procedure followed involves modifying the available concrete section first, and then recalculating the amount of rebar necessary. Square sections were used in all cases. It should be noted that, given the means used during execution, column dimensions were modified in increments of $5 \mathrm{~cm}$. However, in order to obtain graphs with greater continuity, increments of $1 \mathrm{~cm}$ were modeled.

\subsection{Sizing guidelines for columns}

Considering the same gravitational loads (selfweight, permanent loads and imposed loads) and the different project locations, different wind actions and snow loads were taken into consideration for each building. The necessary amount of rebar was determined by varying the column section $\left(\mathrm{A}_{\mathrm{c}}\right)$. The sizing guidelines for rebar $\left(\mathrm{A}_{\mathrm{s}}\right)$ are based on regulation EHE-08 (39) which follows the Eurocode guideline EN 1992-1-1 on the design of concrete structures. Fulfillment of the following aspects also had to be verified: durability, ultimate limit states (ULS) and serviceability limit states (SLS).

The most relevant aspects of ultimate limit states are indicated below:

Minimum longitudinal reinforcement for sections in simple or composite compression [1]:

$$
A_{s}^{\prime} \cdot f_{y c, d} \geq 0.1 \cdot N_{d}
$$

Maximum longitudinal reinforcement for sections in simple or composite compression [2]:

$$
A_{s}^{\prime} \cdot f_{y c, d} \geq f_{c d} \cdot A_{c}
$$

Where:

$A_{s}^{\prime}$ : Area of the total passive reinforcement in compression.

$f_{v c, d}$ : Design strength of the steel in compression. $N_{d}$ : Factored normal acting compression forced.

$f_{c d}$ : Design value of concrete compressive strength.

$A_{c}$ : Area of the total concrete section.

Limit state of failure due to shear [3]:

$$
\begin{aligned}
& \eta_{1}=\sqrt{\left(\frac{V_{r d 1, x}}{V_{u 1, x}}\right)^{2}+\left(\frac{V_{r d 1, y}}{V_{u 1, y}}\right)^{2}} \leq 1 \\
& \eta_{2}=\sqrt{\left(\frac{V_{r d 2, x}}{V_{u 2, x}}\right)^{2}+\left(\frac{V_{r d 2, \mathrm{y}}}{V_{u 2, \mathrm{y}}}\right)^{2}} \leq 1
\end{aligned}
$$

Where:

$V_{r d l i}$ : Design values of the effective shear force produced by external actions.

$V_{u 1}$ : Ultimate shear force failure due to diagonal compression.

$V_{u 2}$ : Ultimate shear force failure due to tensile strength.

Limit state at failure under normal stresses [4]:

$$
\eta_{1}=\sqrt{\frac{N_{e d}^{2}+M_{e d, x}^{2}+M_{e d, y}^{2}}{N_{R d}^{2}+M_{R d, x}^{2}+M_{R d, y}^{2}}} \leq 1
$$

Where:

$N_{e d}$ : Factored normal acting compression forced. $M_{\text {edi }}$ : Design moment in the critical verification section taking into account first order effects.

$N_{R d}$ : Maximum normal acting compression resisted by the critical section.

$M_{\text {Rdi }}$ : Maximum moment resisted by the critical section.

Figure 2 illustrates the combination of normal loads.

In the limit state check for instability, the second order effects can be disregarded since the mechanical slenderness of $\lambda$ columns is less than the slenderness of the lower limit $\lambda_{\text {inf }}$.

\subsection{Calculating resistance capacity}

The final resistance capacity of the sections was calculated based on the following general hypothesis: failure is characterized by the value of strain in specified fibers of the section, defined by failure deformation (39). Plane section before bending will remain plane after bending and the strain $\varepsilon_{\mathrm{s}}$ in passive reinforcements remains equal to that of the concrete surrounding them.

Diagrams of both materials, concrete and steel, are included below in Figure 3. The stress-strain diagram for concrete is a rectangular parabola. The tensile strength of the concrete was not considered. The stress-strain diagram of steel in the passive reinforcements is considered to be rectilinear.

Where:

$f_{c d}$ : Design value of concrete compressive strength.

$\varepsilon_{\mathrm{c} 0}$ : Maximum compressive strain in the concrete under simple compression.

$\varepsilon_{\mathrm{cu}}$ : Maximum compressive strain in the concrete under bending.

$\mathrm{f}_{\mathrm{yd}}$ : Design strength of the steel .

$\varepsilon_{\max }$ : Maximum strain of steel in tension.

The general equations of balanced forces and moments were applied to the resulting strains in the section, as shown in Figure 4. 

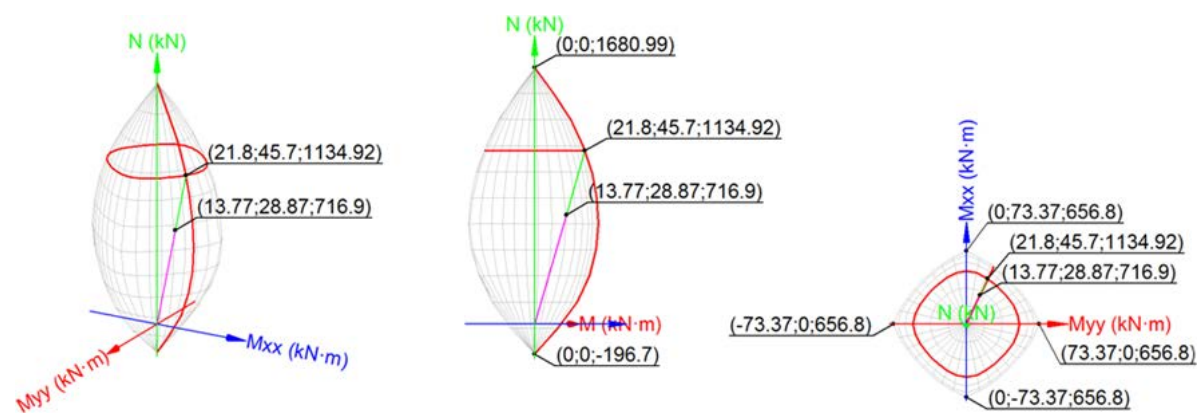

FIGURE 2. Example of combination of normal stresses.
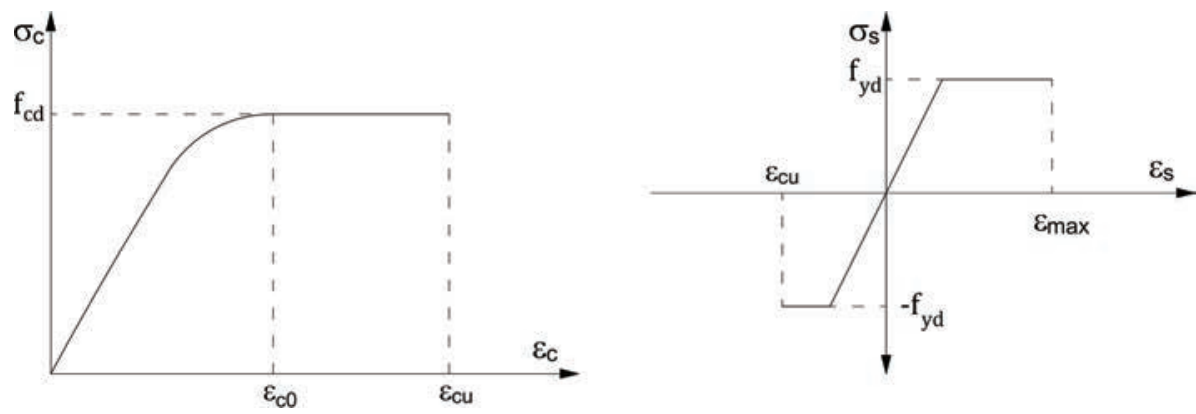

FIGURE 3. Design stress-strain diagram for concrete and steel in passive reinforcements.

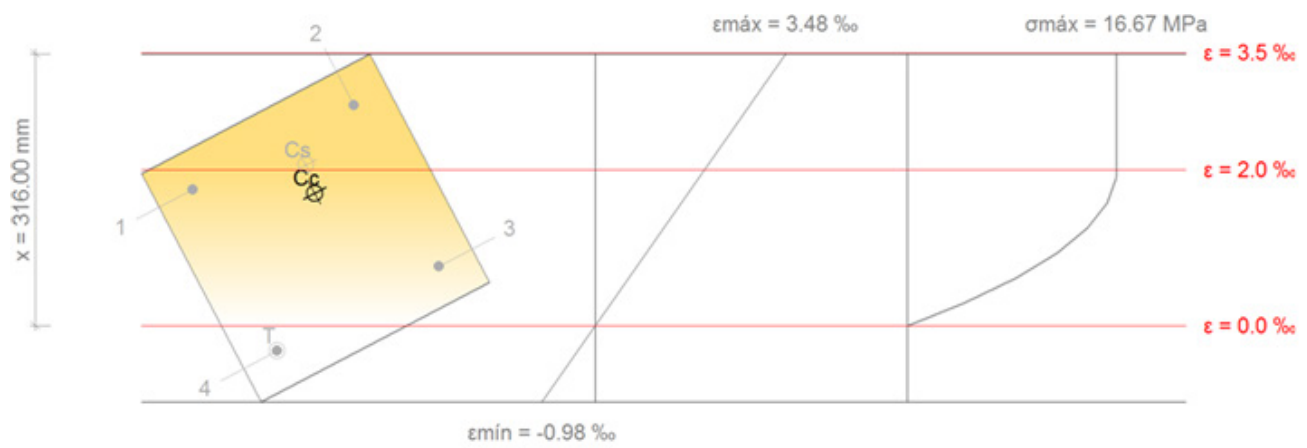

a)

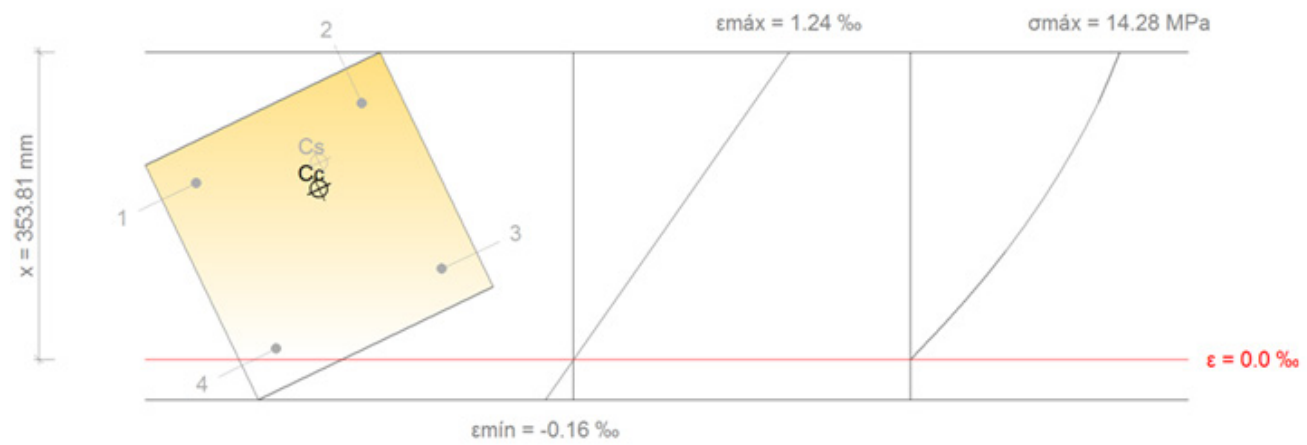

b)

FIGURE 4. Section equilibrium for failure (a). Section equilibrium for loads design (b). 
These checks (ULS and SLS) were performed on each section of the column and on all columns. This process identifies the reinforcement necessary $\mathrm{A}_{\mathrm{s}}$ (normal stresses, failure due to shear and failure due to torsion) for concrete section $\mathrm{A}_{\mathrm{c}}$. The various column sections in a structure are under different stresses (greater stress on lower sections). The design strategy herein focused on designing columns for the different buildings by varying the $A_{s} / A_{c}$ ratio. Therefore, for each building, after a structural analysis and subsequent sizing, the total quantities of steel and concrete used to make the columns could be determined.

At this point, based on the data included in Tables 1 and 2, an economic and environmental assessment of each case can be conducted. The means and costs of executing the formwork were identified as constants. Thus, variations in both costs and emissions can be attributed to cement production (according to the concrete mix) and rebar [5].

$$
\begin{aligned}
& \operatorname{Cost}(€)=\sum_{i=1}^{n} M_{i} \times \gamma_{i} \\
& \text { Emissions }(\mathrm{kg} \mathrm{CO} \mathrm{Eq})=\sum_{i=1}^{n} M_{i} \times \Psi_{i}
\end{aligned}
$$

Where:

$M_{i}$ represent the quantities of materials used to make the columns (rebar and concrete).

$\gamma_{i}$ indicate the unit costs of the materials. Tables 1 and 2.

$\psi_{i}$ indicate the equivalent $\mathrm{CO}_{2}$ emissions corresponding to the materials. Tables 1 and 2 .

This process created a solution map for the column design, incorporating the effects of the design and execution parameters. Figure 5 shows the abovementioned calculation applied wherein the combination of rebar and concrete is varied by the $\mathrm{A}_{\mathrm{s}} / \mathrm{A}_{\mathrm{c}}$ ratio.
Obtaining the equations and their results allowed us to determine the minimum costs and impacts for each building. The minimum values were determined for each modeled building: the cost and the environmental impact (black arrow), as well as the optimal combination of rebar and concrete (red arrow). Once the data was compiled for all the buildings, the impact of modifying each variable factor on the models could be appreciated. These variables were defined in the project and/or execution phases.

All cases complied with the limitations mandated by regulations. These limitations affect the minimum column size $(25 \times 25$ centimeters $)$ and the minimum and maximum amounts of rebar to be incorporated.

\section{RESULTS}

To analyze the results, tables and graphs have been prepared based on the minimum values obtained in each modeled building. This format is intended to highlight the impact of the different parameters on the cost and emissions generated.

The factors affecting material consumption and emissions were determined during the project and execution phases. Two graphs are presented that contain the minimum values, costs and generated emissions corresponding to the different locations and design strengths. Once these values were identified in the project phase, the type of cement had to be selected in the execution phase. The results are presented, considering concrete mixes CEM-I and CEM-II. The economic costs are depicted in Figure 6, and the emissions in Figure 7.

Based on the above figures, one can conclude that the type of concrete used in the design (and selected during the design phase) has a significant effect. However, the use of one type of cement or another does not have a relevant impact on the final cost of the columns. For the case study, the use of design strength C-40 was beneficial as it cut costs by up to $15 \%$. The concrete most often utilized to produce this type of

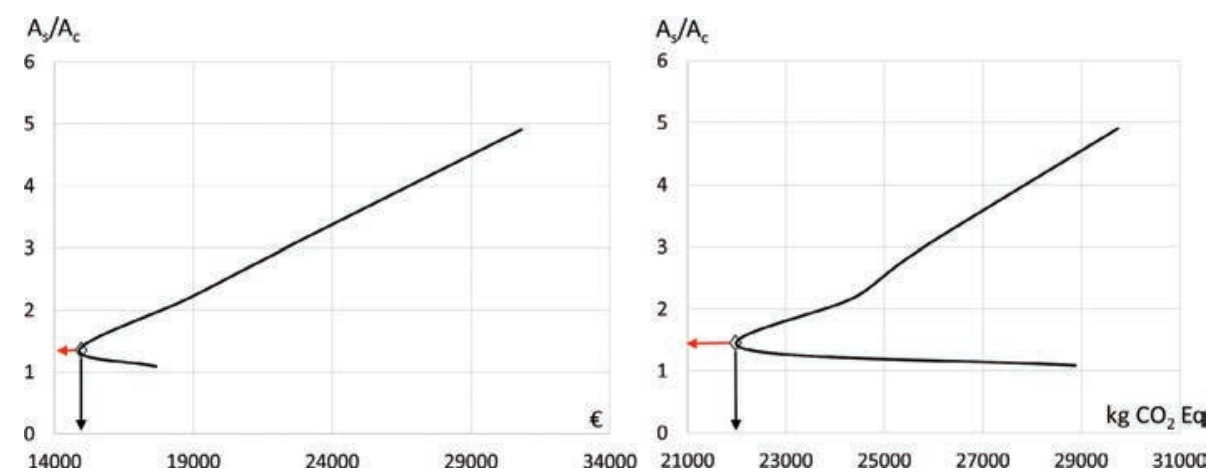

Figure 5. Obtaining $\mathrm{A}_{\mathrm{s}} / \mathrm{A}_{\mathrm{c}}$ for minimum Cost $(€)$ and minimum emissions $\left(\mathrm{kg} \mathrm{CO}_{2} \mathrm{Eq}\right)$. 

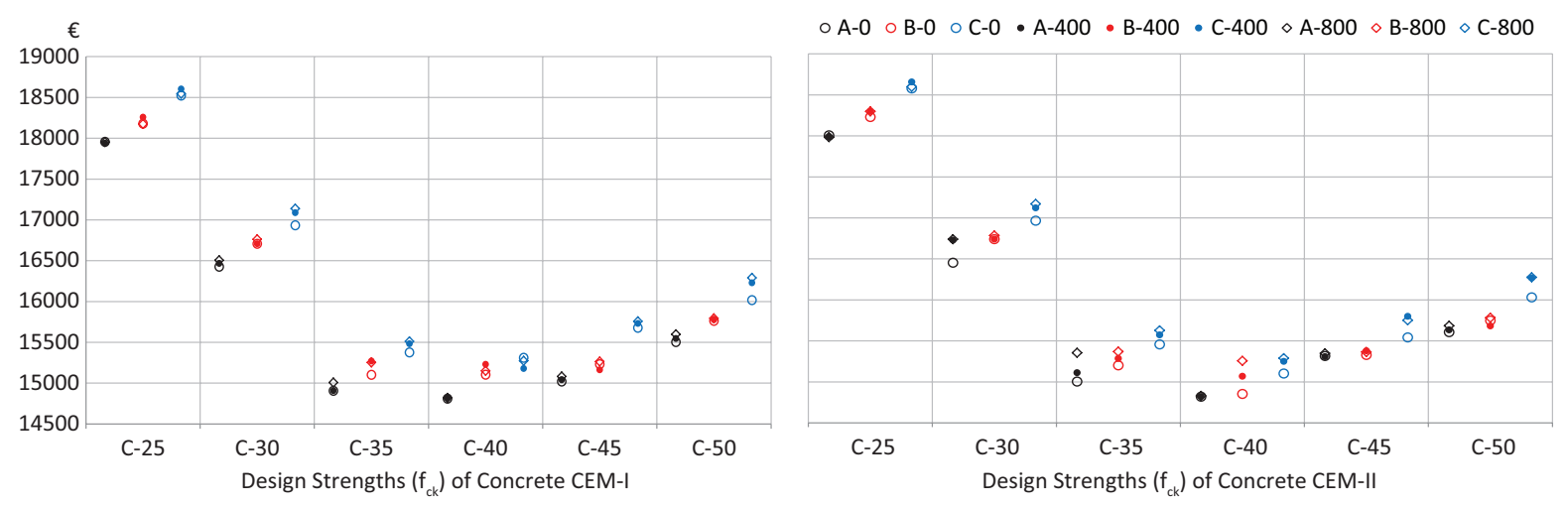

Figure 6. Minimum costs in Euros for the different locations.
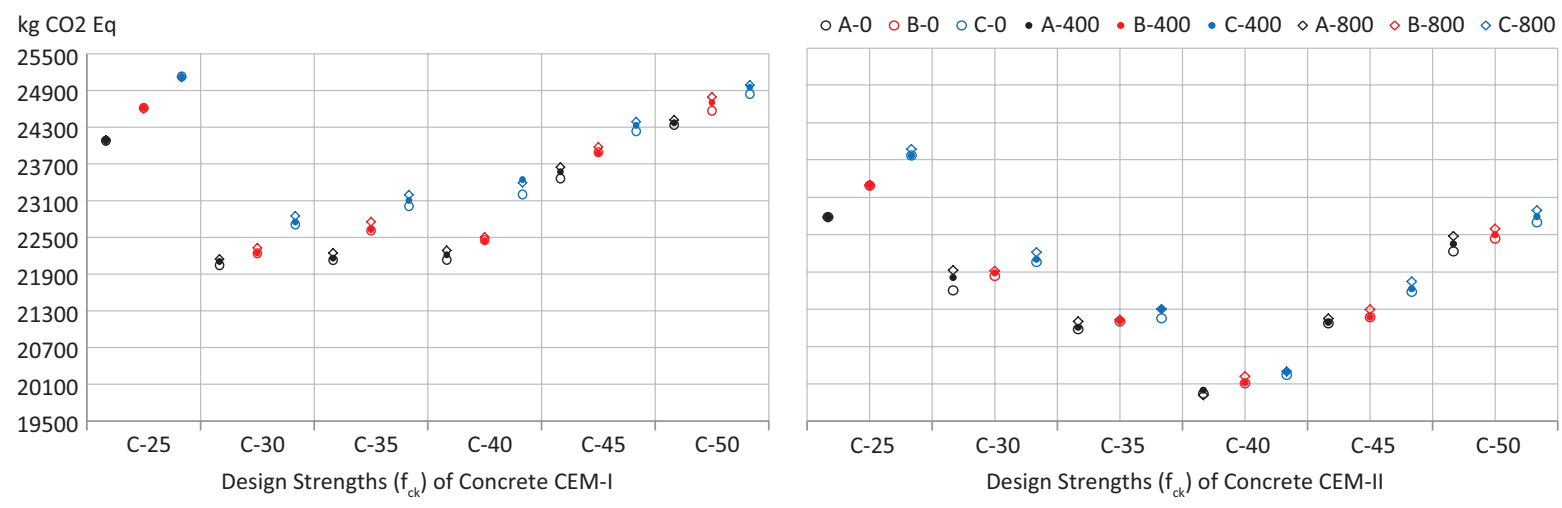

FIgURE 7. Minimum emissions in $\mathrm{kg}$ of $\mathrm{CO}_{2} \mathrm{Eq}$ for the different locations.

column is C-25, which also leads to the worst economic results. Better concrete strength performance is achieved with a greater quantity of cement, although it generates higher emissions and costs, using smaller sections can compensate for this fact. Emissions reduction is influenced by the type of cement used. For example, for CEM-I, concretes C-30, C-35 and $\mathrm{C}-40$ all behave similarly; while if CEM-II is used, C-40 concrete generates the lowest emissions.

The decision to use CEM-I or CEM-II was made during the execution phase. This decision may fall under the responsibility of two different persons: the concrete plant technician or the project manager. Who exactly makes the decision depends on the supply contract. If concrete is chosen based on its performance, the plant technician chooses the type of cement. Whereas if the concrete is selected according to dosing, then the project manager decides on the type of cement. Either way, in light of the results, the economic repercussions are not relevant. But the environmental impact is: emissions generated decreased by up to $10 \%$.

During the project phase, the decisions regarding building location had different implications. For instance, the wind zone had a greater impact than the topographic altitude. Table 4 lists the relative value of 100 for wind zone $A$ and for each type of design strength. The relative average increases and
TABLE 4. Evolution of economic and environmental costs by wind zone

\begin{tabular}{cccccc}
\hline & \multirow{2}{*}{$\begin{array}{l}\text { Wind } \\
\text { zone }\end{array}$} & \multicolumn{2}{c}{ Cost $(\boldsymbol{\epsilon})$} & \multicolumn{2}{c}{ Emissions $\left(\mathbf{C O}_{2}\right)$} \\
\cline { 3 - 6 } & Average & $\sigma$ & Average & $\sigma$ \\
\hline \multirow{6}{*}{ CEM-I } & $\mathbf{A}$ & 100 & - & 100 & - \\
& $\mathbf{B}$ & $101.62 \%$ & $0.47 \%$ & $101.59 \%$ & $0.54 \%$ \\
& $\mathbf{C}$ & $103.65 \%$ & $0.59 \%$ & $103.59 \%$ & $0.92 \%$ \\
& $\mathbf{A}$ & 100 & - & 100 & - \\
CEM-II & $\mathbf{B}$ & $100.92 \%$ & $0.78 \%$ & $101.02 \%$ & $0.58 \%$ \\
& $\mathbf{C}$ & $102.89 \%$ & $0.67 \%$ & $102.21 \%$ & $1.08 \%$ \\
\hline
\end{tabular}

their standard deviations were obtained for cost and emissions for the various wind zones. Variation ranges between $1.02 \%$ and $3.59 \%$ for $\mathrm{CO}_{2}$ emissions and $0.92 \%$ and $3.65 \%$ for costs.

If the topographic altitude is set at 100 for level 0 and for each type of design strength, the cost and emission variations are lower. In this case, if CEM-I is used, the range of variation is between $0.09 \%$ and $0.57 \%$ for $\mathrm{CO}_{2}$ emissions and between $0.10 \%$ and $0.69 \%$ for cost. Meanwhile, if CEM-II is used, the ranges are between $0.10 \%$ and $0.78 \%$ for $\mathrm{CO}_{2}$ emissions, and between $0.38 \%$ and $1.08 \%$ for cost. Table 5 lists the results. 
TABLE 5. Evolution of economic and environmental costs by topographic altitude

\begin{tabular}{|c|c|c|c|c|c|c|c|c|c|}
\hline \multirow[b]{3}{*}{ Wind zone } & \multirow{3}{*}{$\begin{array}{c}\text { Altitude } \\
\text { (m) }\end{array}$} & \multicolumn{4}{|c|}{ CEM-I } & \multicolumn{4}{|c|}{ CEM-II } \\
\hline & & \multicolumn{2}{|c|}{ Cost $(€)$} & \multicolumn{2}{|c|}{ Emissions $\left(\mathrm{CO}_{2}\right)$} & \multicolumn{2}{|c|}{ Cost $(€)$} & \multicolumn{2}{|c|}{ Emissions $\left(\mathrm{CO}_{2}\right)$} \\
\hline & & Average & $\sigma$ & Average & $\sigma$ & Average & $\sigma$ & Average & $\sigma$ \\
\hline \multirow{3}{*}{$\mathbf{A}$} & $\mathbf{0}$ & 100 & - & 100 & - & 100 & - & 100 & - \\
\hline & 400 & $100.10 \%$ & $0.13 \%$ & $100.23 \%$ & $0.15 \%$ & $100.40 \%$ & $0.63 \%$ & $100.78 \%$ & $0.92 \%$ \\
\hline & 800 & $100.37 \%$ & $0.26 \%$ & $100.47 \%$ & $0.24 \%$ & $100.78 \%$ & $0.92 \%$ & $100.57 \%$ & $0.58 \%$ \\
\hline \multirow{3}{*}{ B } & $\mathbf{0}$ & 100 & - & 100 & - & 100 & - & 100 & - \\
\hline & 400 & $100.34 \%$ & $0.52 \%$ & $100.09 \%$ & $0.21 \%$ & $100.38 \%$ & $0.57 \%$ & $100.10 \%$ & $0.11 \%$ \\
\hline & 800 & $100.33 \%$ & $0.32 \%$ & $100.41 \%$ & $0.30 \%$ & $100.81 \%$ & $0.90 \%$ & $100.40 \%$ & $0.24 \%$ \\
\hline \multirow{3}{*}{$\mathrm{C}$} & $\mathbf{0}$ & 100 & - & 100 & - & 100 & - & 100 & - \\
\hline & 400 & $100.47 \%$ & $0.68 \%$ & $100.40 \%$ & $0.34 \%$ & $101.03 \%$ & $0.42 \%$ & $100.29 \%$ & $0.21 \%$ \\
\hline & 800 & $100.69 \%$ & $0.65 \%$ & $100.57 \%$ & $0.29 \%$ & $101.08 \%$ & $0.46 \%$ & $100.62 \%$ & $0.20 \%$ \\
\hline
\end{tabular}

Once the location was decided, the strength performance of the concrete had to be selected as a design variable. It can be observed that using concretes C-35 and C-40 effectively minimized costs and emissions. Figure 8 shows the average values and their standard deviations when design strength was varied. Once the design parameter was defined, the costs varied depending on whether CEM-I or CEM II was used by a range of $1.15 \%$, while the emissions varied by a range of $10.59 \%$. This study shows that in residential construction, for a similar type of building in any location, minimum cost and emissions can be calculated according to this ratio.

Another significant factor in the design phase is the $\mathrm{A}_{\mathrm{s}} / \mathrm{A}_{\mathrm{c}}$ combination. Modifying the section $\left(\mathrm{A}_{\mathrm{s}} /\right.$ $\mathrm{A}_{c}$ ) affects the average dimension of the columns used in the building. Figure 9 illustrates the aforementioned effect. The value of the average dimension is influenced by the strength performance of the concrete.

To obtain the minimum values for cost and environmental impact, the range of the $\mathrm{A}_{\mathrm{s}} / \mathrm{A}_{\mathrm{c}}$ ratio was determined to be interval 1-2. The values that minimize economic as well as environmental costs were identified $\left(\mathrm{A}_{\mathrm{s}} / \mathrm{A}_{\mathrm{c}}\right)$. Regardless of the wind zone, the design values, and the materials used, Table 6 shows the average results and their deviations.

A compromise must be reached for the $\mathrm{A}_{\mathrm{s}} / \mathrm{A}_{\mathrm{c}}$ ratio. For cost, approximately 1.47 is recommended, whereas the optimal value for emissions is 1.7 . Therefore, a reasonable compromise would be to maintain this ratio between 1.47 and 1.73 . In real projects this ratio is pre-determined, since in those areas where the cost of the land is high, the goal is to minimize the space occupied by columns by reducing the necessary $\mathrm{A}_{\mathrm{c}}$ as much as possible.

\section{CONCLUSIONS}

This study provides information on key factors for the design of columns made in situ. The following conclusions are based on the current technology and costs involved in procuring cement (see EPDs), reinforcing steel, and concrete. How technology and
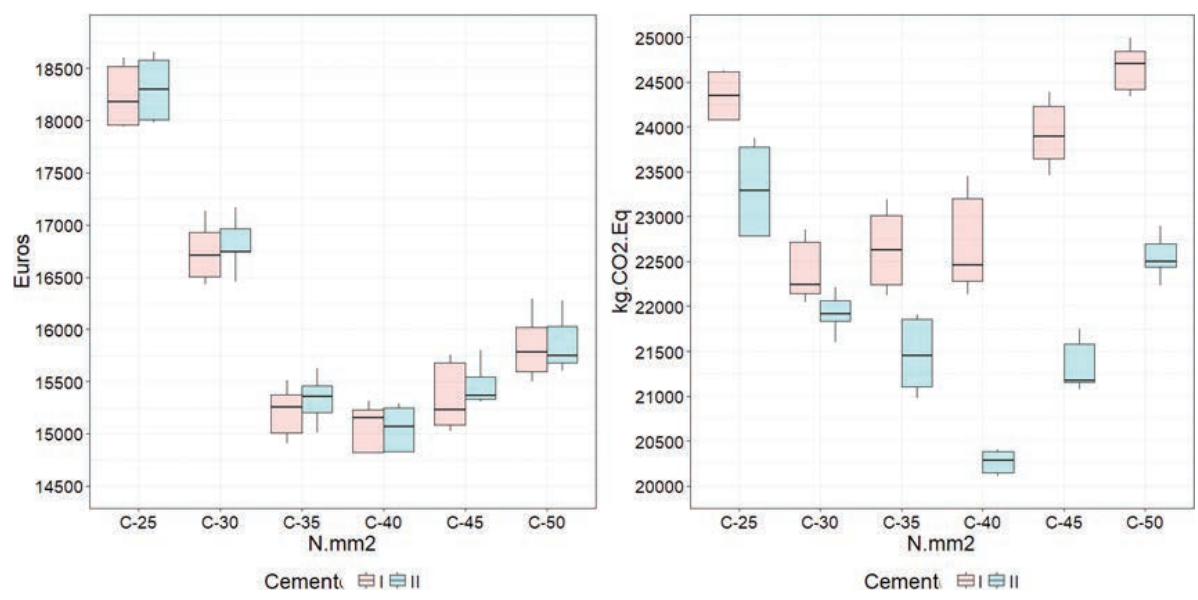

FIGURE 8. Economic and environmental costs by design strength. 


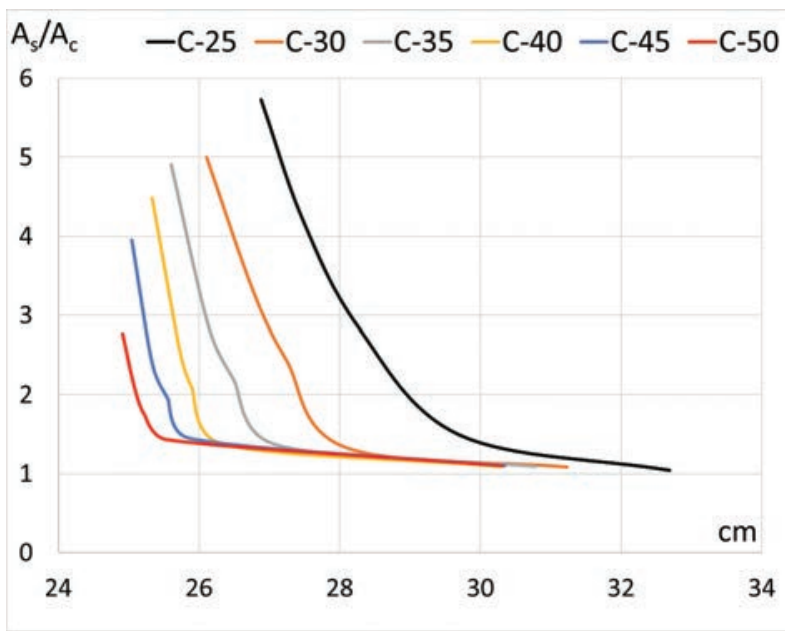

FIGURE 9. Average dimensions of columns in building A-0.

TABLE 6. Average values and standard deviations of $A_{s} / A_{c}$ for economic and environmental costs by wind zone

\begin{tabular}{ccccccc}
\hline & \multirow{2}{*}{$\begin{array}{l}\text { Wind } \\
\text { zone }\end{array}$} & \multicolumn{2}{c}{ Cost } & & \multicolumn{2}{c}{ Emissions } \\
\cline { 3 - 4 } \cline { 6 - 7 } & Average & $\sigma$ & & Average & $\sigma$ \\
\hline \multirow{3}{*}{ As/Ac } & A & 1.467 & 0.076 & & 1.683 & 0.080 \\
& B & 1.477 & 0.109 & & 1.720 & 0.052 \\
& C & 1.475 & 0.103 & & 1.730 & 0.054 \\
\hline
\end{tabular}

material production costs may evolve over time has not been addressed in this article. We offer a detailed account of the conclusions reached for each variable examined in this study.

The location variables have a small impact in terms of environmental and economic costs. The different possible building locations produced variations below $4 \%$. The wind zone variable exhibited greater influence than topographic altitude.

Significant variations were observed when the concrete design strength was modified. This variable affected both economic and environmental costs and the average dimensions of the resulting columns. Concrete with a design strength $\left(\mathrm{f}_{\mathrm{ck}}\right)$ of 40 $\mathrm{N} / \mathrm{mm}^{2}$ mixed with cement type CEM-II was found to be the best choice for the loads modeled in this study. With this option and depending on the geometry employed $\left(\mathrm{A}_{\mathrm{s}} / \mathrm{A}_{\mathrm{c}}\right)$, the minimum cost or emissions can be obtained. Economic costs decreased by up to $17.83 \%$ and $\mathrm{CO}_{2}$ emissions fell by up to $13.59 \%$. These percentage values for economic and environmental savings are in comparison with the minimum values obtained using concretes $\mathrm{C}-25$ and CEM-II.

The percentage of the quotient between the area of rebar and of the concrete section $\left(\mathrm{A}_{\mathrm{s}} / \mathrm{A}_{\mathrm{c}}\right)$ is a relevant design parameter. The optimum value for this ratio was determined to be between 1.47 and 1.73 , regardless of the design strength of the concrete used. The study shows that modifying the sections gradually, centimeter by centimeter, minimizes costs and allows for smaller middle sections. On the other hand, when perforated plates are utilized in the execution phase, the columns must increase by increments of $5 \mathrm{~cm}$, which entails consequences for both economic and environmental costs. Future research could examine the possibility of improving the means used during the execution phase to allow for more gradual changes in column sections.

Environmental product declarations - for rebar and cement - have proven to be useful to assess concrete columns in environmental terms.

\section{REFERENCES}

1. Galán-Marín, C.; Rivera-Gómez, C.; García-Martínez, A. (2015) Embodied energy of conventional load-bearing walls versus natural stabilized earth blocks. Energy Build. 97, 146-154. https://doi.org/10.1016/j.enbuild.2015.03.054.

2. Park, H.; Kwon B.; Shin Y.; Kim Y.; Hong T.; Choi S. (2013) Cost and $\mathrm{CO}_{2}$ Emission Optimization of Steel Reinforced Concrete Columns in High-Rise Buildings. Energies 6, 5609-5624. https://doi.org/10.3390/en6115609.

3. Ferreiro-Cabello, J.; Fraile-Garcia, E.; Martinez de Pison Ascacibar E.; Martinez de Pison Ascacibar, F. J. (2016) Minimizing greenhouse gas emissions and costs for structures with flat slabs. J. Clean. Prod. 137, 922-930. https:// doi.org/10.1016/j.jclepro.2016.07.153.

4. Kripka, M.; Medeiros, G. F.; Fraga, J. L. T.; Marosin, P. R. (2014) Minimizing the environmental impact of R-C structural elements. Eng. Optim. 727-730. https://www. researchgate.net/publication/265597500_Minimizing_the_ environmental_impact_of_R-C_structural_elements

5. Guardigli, L. (2014) Comparing the environmental impact of reinforced concrete and wooden structures. Eco-Efficient Constr. Build. Mater. 49, pp. 407-433. https:// doi.org/10.1533/9780857097729.3.407

6. Xiao, J.; Wang, C.; Ding, T.; Akbarnezhad, A. (2018) A recycled aggregate concrete high-rise building: Structural performance and embodied carbon footprint. J. Clean. Prod. 199, 868-881. https://doi.org/10.1016/j.jclepro.2018.07.210.

7. Zahra S.; Moussavi Nadoushani, A. A. (2015) Effects of structural system on the life cycle carbon footprint of buildings. Energy Build. 1, 337-346. https://doi.org/10.1016/j. enbuild.2015.05.044.

8. Griffin, C. T.; Reed, B.; Hsu, S.; Cruz, P. J. S. (2010) Comparing the embodied energy of structural systems in buildings. Struct. Archit. 1367-1373.

9. Martí, J. V.; García-Segura, T.; Yepes, V. (2016) Structural design of precast-prestressed concrete U-beam road bridges based on embodied energy. J. Clean. Prod. 120, 231-240. https://doi.org/10.1016/j.jclepro.2016.02.024.

10. Fraile-Garcia, E.; Ferreiro-Cabello, J.; Martinez-Camara, E.; Jimenez-Macias, E. (2016) Optimization based on life cycle analysis for reinforced concrete structures with one-way slabs. Eng. Struct. 109, 126-138. https://doi.org/ 10.1016/j.engstruct.2015.12.001.

11. Miller, S. A.; Horvath, A.; Monteiro, P. J. M.; Ostertag, C. P. (2015) Greenhouse gas emissions from concrete can be reduced by using mix proportions, geometric aspects, and age as design factors. Environ. Res. Lett. 10, 114017. https:// doi.org/10.1088/1748-9326/10/11/114017.

12. Peng, W.; Sui Pheng, L. (2011) Managing the Embodied Carbon of Precast Concrete Columns. J. Mater. Civ. Eng. 23, 1192-1199. https://doi.org/10.1061/(ASCE)MT.1943-5533.0000287.

13. Hong, W.-K.; Park, S.-C.; Jeong, S.-Y.; Lim, G.-T.; Kim, J.-T. (2012) Evaluation of the Energy Efficiencies of Pre-cast Composite Columns. Indoor Built Environ. 21, 176-183. https://doi.org/10.1177/1420326X11420126. 
14. Wu, P.; Pienaar, J.; O'Brien, D. (2013) Developing a lean benchmarking process to monitor the carbon efficiency in precast concrete factories-a case study in Singapore. Coll. Publ. 8, 133-152. https://doi.org/10.3992/jgb.8.2.133.

15. Wu, P. (2014) Monitoring carbon emissions in precast concrete installation through lean production - A case study in Singapore. J. Green Build. 9, 191-211. https://doi. org/10.3992/1943-4618-9.4.191.

16. Oh, B. K.; Park, J. S.; Choi, S. W. Park, H. S. (2016) Design model for analysis of relationships among $\mathrm{CO} 2$ emissions, cost, and structural parameters in green building construction with composite columns. Energy Build. 118, 301-315. https://doi.org/10.1016/j.enbuild.2016.03.015.

17. Choi, S. W.; Oh, B. K.; Park, J. S.; Park, H. S. (2016) Sustainable design model to reduce environmental impact of building construction with composite structures. J. Clean. Prod. 137, 823-832. https://doi.org/10.1016/j. jclepro.2016.07.174.

18. Kripka, M.; de Medeiros, G. F (2012) Cross-Sectional Optimization of Reinforced Concrete Columns Considering both Economical and Environmental Costs. Appl. Mech. Mater. 193-194, 1086-1089. https://doi.org/10.4028/www. scientific.net/AMM.193-194.1086.

19. Heede, P.; Van den, Maes, M.; Gruyaert, E.; Belie, N. De. (2012) Full probabilistic service life prediction and life cycle assessment of concrete with fly ash and blast-furnace slag in a submerged marine environment: a parameter study. Int. J. Environ. Sustain. Dev. 11, 32. https://doi.org/10.1504/ IJESD.2012.049141.

20. García-Segura, T.; Yepes, V.; Alcalá, J. (2014) Life cycle greenhouse gas emissions of blended cement concrete including carbonation and durability. Int. J. Life Cycle Assess. 19, 3-12. https://doi.org/10.1007/s11367-013-0614-0.

21. Yang, K.-H.; Seo, E.-A.; Choi, D.-U. (2014) Effect of fly ash on lifecycle $\mathrm{CO}_{2}$ assessment of concrete structure. Appl. Mech. Mater. 692. https://doi.org/10.4028/www.scientific. net/AMM.692.475

22. Magudeaswaran, P.; Eswaramoorthi, P. (2015) Use of industrial waste materials in sustainable green high-performance reinforced concrete short columns. Int. J. Earth Sci. Eng. 8.

23. Albitar, M.; Mohamed Ali, M. S.; Visintin, P. (2017) Experimental study on fly ash and lead smelter slag-based geopolymer concrete columns. Constr. Build. Mater. 141, 104-112. https://doi.org/10.1016/j.conbuildmat.2017.03.014.

24. Zhang, Y. F.; Zhao, J. H.; Cai, C. S. (2012) Seismic behavior of ring beam joints between concrete-filled twin steel tubes columns and reinforced concrete beams. Eng. Struct. 39, 1-10. https://doi.org/10.1016/j.engstruct.2012.01.014.

25. Hirade, T.; Odajima, N.; Kimura, H.; Kaneko, H.; Yonezawa T. (2014) Structural performance of the steel-bar-reinforced concrete-filled circular thin steel tubular columns using high slag cement. J. Struct. Constr. Eng. (Transactions AIJ) 79, 651-660.

26. AENOR GlobalEPD Program. Environmental Product Declaration Long steel laminate construction unalloyed hot oven from: corrugated bars. 1-12 (2014).

27. AENOR GlobalEPD Program. Environmental Product Declaration Cement CEM I. 1-12 (2014).

28. AENOR GlobalEPD Program. Environmental Product Declaration Cement CEM II. 1-12 (2014).

29. AENOR GlobalEPD Program. Environmental Product Declaration Cement CEM III. 1-12 (2014).

30. AENOR GlobalEPD Program. Environmental Product Declaration Cement CEM IV. 1-12 (2014).

31. AENOR GlobalEPD Program. Environmental Product Declaration Cement CEM V. 1-12 (2014).

32. Fraile-Garcia, E.; Ferreiro-Cabello, J.; Martinez-Camara, E.; Jimenez-Macias, E. (2015) Adaptation of methodology to select structural alternatives of one-way slab in residential building to the guidelines of the European Committee for Standardization (CEN/TC 350). Environ. Impact Assess. Rev. 55, 144-155. https://doi.org/10.1016/j. eiar.2015.08.004

33. Yang, K. H.; Jung, Y. B.; Cho, M. S.; Tae, S. H. (2015) Effect of Supplementary Cementitious Materials on Reduction of $\mathrm{CO}_{2}$ Emissions From Concrete. Handb. Low Carbon Concr. 103, 774-783. https://doi.org/10.1016/j. jclepro.2014.03.018.

34. Park, H. S.; Lee, H.; Kim, Y.; Hong, T.; Choi, S. W. (2014) Evaluation of the influence of design factors on the $\mathrm{CO} 2$ emissions and costs of reinforced concrete columns. Energy Build. 82, 378-384. https://doi.org/10.1016/j. enbuild.2014.07.038.

35. Jeong, J.; Taehoon H.; Changyoon J.; Jimin K.; Minhyun L.; Kwangbok J.; Seunghwan L. (2017) An integrated evaluation of productivity, cost and $\mathrm{CO}_{2}$ emission between prefabricated and conventional columns. J. Clean. Prod. 142, 2393-2406. https://doi.org/10.1016/j.jclepro.2016.11.035.

36. Li, H.; Deng, Q.; Xia, B.; Zhang, J.; Skitmore, M. (2019) Assessing the life cycle $\mathrm{CO}_{2}$ emissions of reinforced concrete structures: Four cases from China. J. Clean. Prod. 210, 1496-1506. https://doi.org/10.1016/j.jclepro.2018.11.102.

37. Plataforma Tecnologica Española del Hormigón. Hormigón: Un Material Para Aumentar la Sotenibilidad de la Construcción. PTEH (2014). Available at: https:// www.ieca.es/publicaciones/. (Accessed: 1st December 2017).

38. CYPE Ingenieros S.A. CYPE Ingenieros S.A. Software for Architecture, Engineering and Construction. Spain, 2016. (2017).

39. Ministry of Public Works Spain. Code on Structural Concrete (Spanish abbreviation - EHE-08). (2008). 